\title{
More green space in a denser city: \\ Critical relations between user experience and urban form
}

Paper submitted to Urban Design International

(revised 03/10/2009)

\author{
Author: Alexander Ståhle \\ Spatial Analysis and Design, School of Architecture and the Built Environment, Royal \\ Institute of Technology \\ Address: S-100 44 Stockholm, Sweden \\ Email: alexander.stahle@spacescape.se
}

Telephone: +46 (0)8 7906021 or +46 (0)70 6995319 


\begin{abstract}
This paper suggests new tools for understanding and measuring how urban design affects green space accessibility: how urban structure distributes open space to people and how it creates users and stakeholders. Two similar questionnaires from 2001 and 2004 reveal that citizens in some dense inner city districts experience higher green space accessibility than citizens in some low-density "green" suburbs in Stockholm. This peculiar result was the starting point of testing old and new measures in ten different city districts using a new GISapplication “The Place Syntax Tool” (PST). PST makes it possible to calculate the open space accessibility from every address point in an urban area. A new measure, which considers range (1000 meter), orientation (axial line distance), green space size (sqm), and number of use values, correlated considerably better to the questionnaires $(\mathrm{R} 2=0.74 \mathrm{p}<0.001)$ than any of the conventional measures. Correlation was also found when comparing another questionnaire that asked participants how often they go to their favourite green area and axial line accessibility to green areas ( $\mathrm{R} 2=0.77, \mathrm{p}=0.018$ ). Consequently, cognitive anthropocentric measures of accessibility and attraction can change the common opinion of open space and "green" from a static to a dynamic urban entity.
\end{abstract}

Keywords: green space, urban density, accessibility analysis, place syntax, Stockholm

\title{
1. Introduction
}

Two prevailing urban planning schemes - densification and sprawl - have dominated the 21st century. These strategies, which have obvious consequences for green and open space, have frequently led to deadlocks in planning, especially concerning green space exploitation. This conflict describes the well-known and long-debated dichotomy within urban planning and design: ‘dense' or “green'. If Nozzi (2003) thinks that transportation planning is the key to cope with sprawl, the findings presented in this paper show that open space planning can be just as powerful a tool to manage urban growth such as a qualitative densification of sprawl.

The strong dichotomy 'dense' or 'green', which I will claim can be very misleading, is illustrated by the urban theorist Henri Lefebvre's observation (1985) that there is a conflict between "the right to the city" and "the right to nature". In planning processes, this antithesis can roughly be said to be represented by "the urbanists", who fight for urban businesses, housing, social integration et cetera., and the "the environmentalists”, who fight for the conservation of green belts, parks, and open spaces in the city.

Much has been written from the urbanist side of architecture and planning theory by both neomodernists and new urbanists (e.g., MVRDV 1998, CNU 1999) to diminish or question the need or importance of green in cities, a claim that often is placed in relation to the modernist planning paradigms (e.g., CIAM, Le Corbusier, Walter Gropius). There has also been recent research showing correlations between the amount of green space and the accessibility to service, which emphasises the idea of an absolute relation between green space and urban quality (Reneland 1999).

The environmentalist side exists mainly on two levels: on the national policy level (e.g., NGOs like Sierra Club in the USA or GOs like English Nature in the UK) or on the local 
action group level, which is often been described as Not-In-My-Backyard groups (NIMBY). Both levels are well interconnected and also well informed about recent science mostly concerning ecology, transportation, and medicine. The strongest conservation arguments put forth principally concerns about biodiversity and health (e.g., World Commission On Environment and Development 1987, Ulrich 1984, Kaplan \& Kaplan 1989).

This fight between 'dense' and 'green' has been going on ever since the birth of modern planning, and one can almost say that it is part of the origins of modern planning theory, roughly beginning with the $19^{\text {th }}$ century regularism. The first regularists, Baron Haussmann and others, were to a large extent dealing with open space structuring. Green and open space was also one of the fundamentals in Ebenezer Howard's famous diagram for the town-country (1945), and Le Corbusier's idea of "La ville verte" - the green city. They have all tried to merge 'dense' and 'green' and have claimed, as Raymond Unwin did 1912 and as Richard Rogers and Richard Burnett do today (2000), that "[d]ensity has little to do with overcrowding or town cramming. It has everything to do with design of the environment”. Being in a postmodern state, we now ask these questions: What have we learned from these theories? Which theories succeeded and which did not?

Many urban researchers have shown that the $20^{\text {th }}$ century sprawled city is suffering from many social and environmental maladies. Dolores Hayden (2003) among others argues that it is this existing sprawl that is the most critical urban design and planning task for the $21^{\text {st }}$ century. This leads to the question of how to re-urbanize suburbia, to "grow the city inwards" (Stockholms stad 1999). Following from this question, Dutch architects at Xaveer De Geyter (2002) claim in their book After sprawl that the most pressing question is this: What to do with the open space structures of suburbia? Since most open space that can be exploited in cities, in terms of surface area, is "green”, this paper focuses mainly on public green space.

Efficient green space structure design is consequently one of the crucial issues of "smart growth". Anyone working with urban design knows that urban development on green space is not always bad for the "green". It could be that less green space can be restructured and better distributed spatially. In this paper, which is a summary of my licentiate thesis (Ståhle 2005), I have tried to analyze how and when this may be the case and there are a few findings that question much of the conventional dense-green dichotomies. I have used a combination of space syntax research and geographic accessibility research in what has been called the 'Place syntax model' (Ståhle et al. 2005) to develop new measures of green space structure analysis. The Place syntax model enables new types of green space accessibility analysis that is evidently more realistic than any of the conventional green space measures used in urban planning and design. In this paper, evidence is presented that new combined measures can highly correlate with users' experience of green space accessibility, an approach that makes critical relations between experience and urban form more clear and pinpoints how green space structure design can support sustainable urban development. 


\section{Methods}

\subsection{Green space measures in practice}

There is little doubt that green and open space is a vital part of sustainable urbanism. There are practically no cities, or planning for that matter, that exist without parks and squares. The precious question is how to deal with it, how to plan and design it.

Since the birth of modern planning, quantitative measures and standards for open space have been successively developed to define density and attraction in urban settlements. One of the first theorists in the field was Richard Baumeister who 1876 claimed that open space area per person is a rough but useful measurement of attraction. This is what one could call an area measure. The German researcher Anton Hoenig introduced the open space area ratio in the 1920s, which is calculated by dividing open space area with total floor area (instead of persons). This measure came to be very influential in the modernist planning movement, not at least for public planning policies in the Nordic countries. Patrick Abercrombie's Greater London Plan from 1944 contains guidelines that parks and playfields should be at least 40 sqm per person. These are all area based measures. The need for children's playgrounds became one of the driving forces for the development of open space standards. The Stockholm General Plan from 1952, which in many ways is much a replica of Abercrombie's work, introduced new standards for playground accessibility: 300 meters was set as maximum distance to playgrounds based on a questionnaire to kindergartens in Stockholm. This is what one could call an accessibility or location based measure.

During the 1960 and 70s, greater systems of open space standards were developed, mixing different kinds of measures. To conclude, two basic types of measures have been used and are in principle still in use by National Recreation and Playground Association in USA (Lancaster 1987), European Common Indicators in the EU (ECI 2003), English Nature in UK (Harrison et al. 1995), and The National Board of Housing Building and Planning in Sweden (Boverket 1999). They are open space per person within an area and open space accessibility. The latter consists of norms defining the maximum distance (e.g., 300 meters) to a minimum size open space (e.g., neighbourhood park).

Basically, open space standards measure two things: attraction and accessibility. Attraction has in planning practice (Table 1) been measured in surface area (square meters).

Accessibility has been measured in metric distance (meters). The major question, however, remains: Are these measurements true to people's common experience? Few scientific studies have addressed this question (De Clercq 2007, Van Herzele 2003). The findings in this study indicate that there is a need to more thoroughly consider the concepts of attraction and accessibility.

\subsection{Theoretical framework and a model for new measures}

Studying the relation between urban attraction and accessibility is one of the core aims of research in urban morphology. There are, however, many ways to measure attraction and accessibility, and the methods are not always obvious within the realms of urban morphology. From the point of view of the research question - how to measure green space accessibility - 
environmental economics and architecture theory seem to be useful to grasp the social complexity of green space attraction and accessibility.

\begin{tabular}{|l|c|c|}
\hline & Accessibility & Attraction \\
\hline $\begin{array}{l}\text { Planning } \\
\text { practice }\end{array}$ & Metric distance $(\mathrm{m})$ & Surface area $\left(\mathrm{m}^{2}\right)$ \\
\hline Proposed & Axial distance (steps) & Use values (number of) \\
\hline
\end{tabular}

Table 1. Measures (and units) of open space attraction and accessibility used in planning practice today and the added measures proposed and tested in the study.

To integrate the economical model for attraction and the architectural model for accessibility, accessibility models of contemporary GIS-research, commonly used in urban morphology, urban geography and transport research is implemented.

\subsubsection{Basic concepts}

First, the concept of open space has to be defined. In urban planning, open space is usually defined as the publicly owned land that is preserved from urbanization (streets and buildings), but it also include private land, such as courtyards and gardens. I suggest this definition: 'Open space refers to outdoor space that can be urbanized'. This means parks, nature areas, agricultural land, beaches, squares, parking lots, yards, and gardens, but not streets, roads, and railroads. Blue space, water areas, is theoretically within this definition, but practically they are very seldom objects for urban development, but part of the attraction of open space. In my analyses, water areas are managed as attractors (that create use value), but not areas (that make open space).

Related urban planning concepts are green space and public space. "Green” spaces, areas, and structures have been widely used the last centuries mainly because of the strong dominance of the ecological, environmental, biodiversity, and sustainability paradigms in planning. The concept of "green" has been very influential in urban planning as objects for conservation, as mentioned in the introduction. Green space is simply open space (partly) covered by vegetation or natural features.

Public space most commonly refers to all land and spaces that are accessible to the public, indoors or outdoors. Public spaces in the city inherit complex territorialities whether they are appropriated and locally privatised by different people or groups (Whyte 1980), or whether they are located globally or locally and integrated in the city (Hillier \& Hanson 1984). Within political economy, the spectrum between public and private can be categorized as types of goods, from pure public goods (air) and common pool resources (parks and squares), to club goods (yards) and private goods (gardens). This typology is based on the goods subtractability and excludability. Urban open spaces are usually seen as common pool resources; they have low excludability as pure public goods, but some subtractability because of crowding and wear and tear. In this paper, primarily publicly accessible open spaces, which emphasize low excludability, will be analysed. 


\subsubsection{Attraction: use value and sociotopes}

As said, open space attraction has traditionally been measured as surface area within urban planning. Now, it is evident that open spaces are different. There is a big span between "untouched" nature and vibrant urban squares. All environments are also different life worlds for different people. The only reasonable way to deal with this phenomenological complexity is to start from the individual and its life world, and from this approach seek the most useful generalisations. Here economical theory has got the concept use value. Use emphasises human action and value the performance of things.

Within environmental economy, one has divided use value into concepts that can also grasp the diffuse values of public goods and common pool resources. This study analyzes direct use value, which refers to actions, experiences, and being on site. The study does not incorporate indirect use value, which refers to the use of open space, such as a view from a window. In addition, no analysis is made on non-use value, which refers to the value of existence (existence value) or the value of possibilities (option value). From now on, the term use value is used for direct use value.

The question of measuring use value needs to be specified in units. Use value can basically be measured in two ways: either as diversity (number of use values) or as significance (value). The latter could theoretically be translated to exchange value or monetary value. This has been extensively tested within environmental economy, e.g., by estimating "willingness to pay". It is the former, number of use values or uses that is in focus in this study because it pinpoints the issue of how users appropriate things and places. Use and use values in open space can be described in many ways: anthropologically, sociologically, economically, etc. A set of methods has to be chosen in relation to the social and spatial context studied.

At the urban planning office in Stockholm city (2000-2003), my fellow landscape architect Anders Sandberg and I developed a map for open space use values, the sociotope map (Ståhle 2006). The sociotope was mainly created as a response to the ecological concept biotope. The statement is simply that the same place can be both a forest (biotope) and a playground (sociotope). The sociotope map describes the different uses of places, hence the use values. These have been extracted from extensive user studies, such as several questionnaires, focus groups, and interviews (Ståhle et al. 2003). The Stockholm sociotope map is used in this study (Figure 1) to measure both diversity (1 to 10) and surface area (hectares) of public accessible open and green spaces ( $>0.5$ hectares). 


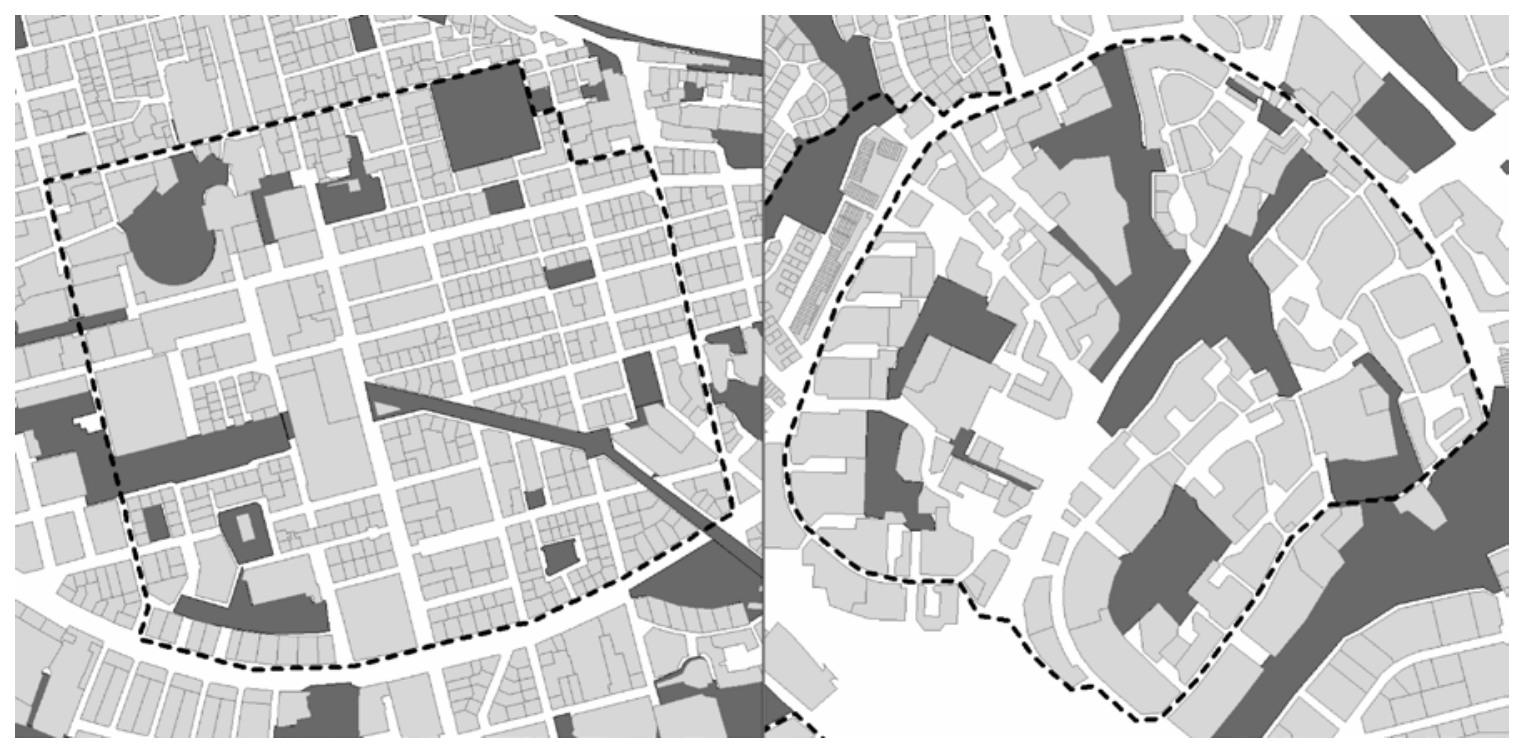

Figure 1. Sociotope maps of the study areas Södermalm (left) and Högdalen (right) showing public accessible open spaces larger than 0.5 hectare. Every sociotope space has its set of use values in the sociotope map database.

In the GIS-analysis ten use values area collected from the sociotope map: water contact, recreational activities, lively place, green oasis, play area, wilderness, picnic, peace \& quite, view point, and gardening \& agriculture. Some words are hard to translate from Swedish because they are extracted from public dialogue and are place specific in the very true sense of the word. But the set of values here selected is an attempt to quantify use value diversity, so that is possible to integrate into the GIS-analysis.

\subsubsection{Accessibility: orientation and axial lines}

An example of a thoroughly tested and researched measure in urban morphology is the axial line developed within Space syntax research. Bill Hillier states the following:

"From an experiential point of view, cities seem to be about seeing and going. Syntactic analysis [integration analysis of axial line maps] confirms this by showing they are structured both to make the physical movement of bodies efficient and to be intelligible to minds. [...] a notion of the directionality of vision is built into the fundamental relation between the metric and the visual properties of spaces”. (2003 p. 6:2)

An axial line is in short 'a walkable line of sight' and an axial map is created by drawing "the least set of such straight lines which passes through each convex space and makes all axial links” (Hillier \& Hanson 1984).

The axial map basically captures the cognitive accessibility in movement space in terms of directionality. With the axial map it is possible to quantitatively measure distance in number of changes in direction, in terms of 'axial steps'. For example, a pedestrian target $(j)$ can be $\mathrm{X}$ meters, but $\mathrm{Y}$ axial steps from a location (i). Integration analyses of axial maps, urban space itself, have been proven to predict many human activities in cities and buildings, especially pedestrian flows in deformed grid structures (Hillier et al. 1993). Axial line (and not metric) 
accessibility to population has also been proven to support pedestrian flow prediction in suburban tree-like grids (Ståhle et al. 2005).

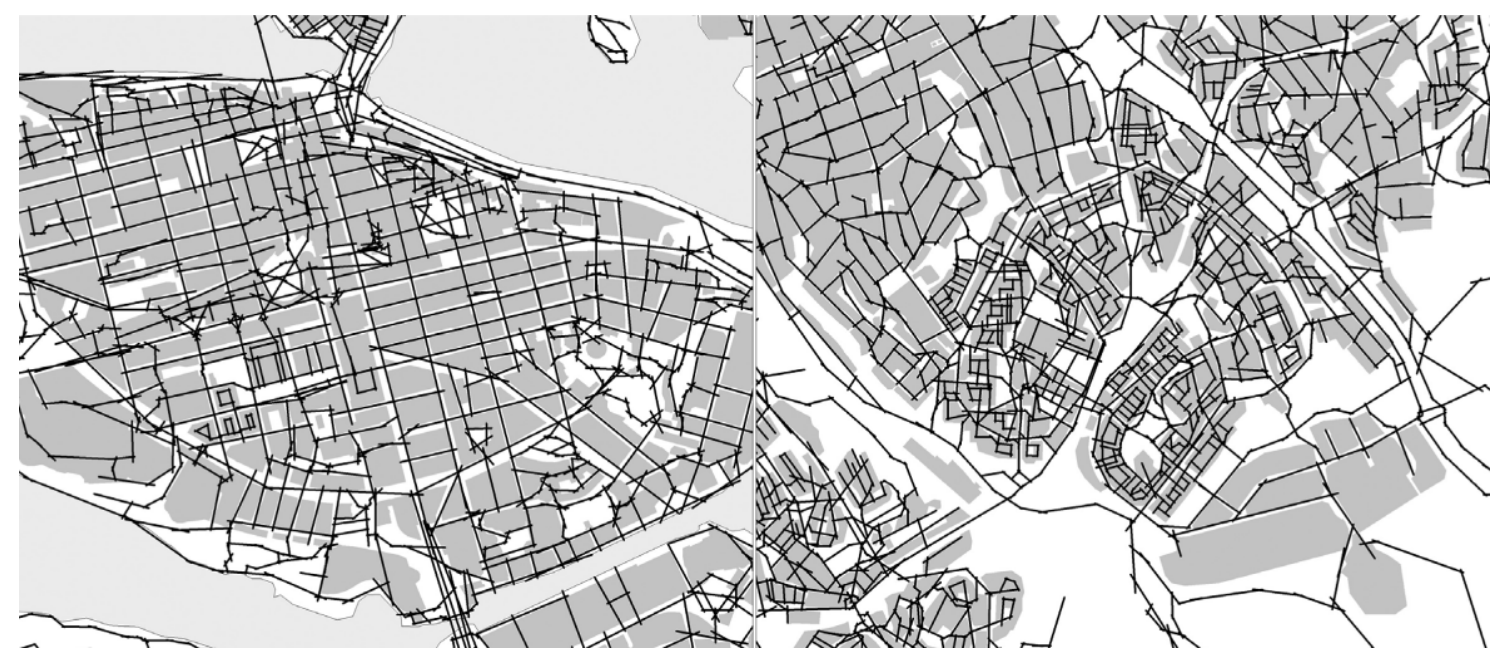

Figure 2. Axial maps of study areas Södermalm (left) and Högdalen (right).

The axial map (Figure 2) covers all walkable urban publicly accessible outdoor movement space, which practically means all streets and pedestrian paths in the city. With the axial map in GIS, it is possible to measure both metric and axial step distance. Metric distance, which emphasises the physical effort to move, is in the analyses aimed at measuring range, i.e., how far one can reach. Hörnsten and Fredman (2000) have shown that people do not usually walk longer than 1000 meters to a recreation area. Accordingly, transportation research generally claims that after 1-1.5 km pedestrians commonly choose other means of transportation.

\subsection{The Place Syntax model}

With the newly developed GIS-application The Place Syntax Tool (PST), it is possible to measure "geographic accessibility with axial lines in GIS" (Ståhle et al. 2005). PST also makes it possible to calculate accessibility with axial lines from every place (address or plot) in an urban area, current or planned. Accessibility analysis, such as the place syntax analysis, deals with the Modifiable Areal Unit Problem (Openshaw 1984 p. 3), which should be considered as a severe limitation for common urban area statistics used in urban planning and design. Green space statistics for a city district can be made sensitive to the internal and external urban structure, which shapes accessibility and, according to my findings, be more true to the citizen's life world. With PST, it is also possible to analyse metric accessibility as in any GIS-network analysis (Ståhle et al. 2005).

The Geographic Information System (GIS) used in the analyses below is MapInfo and the newly developed application the Place Syntax Tool (PST). The GIS-dataset (Figure 3) analysed consists of axial lines, unlink points (disconnects axial lines that do not cross in reality), plot regions (properties), address points (links plots and axial lines), green space regions, and green space entries (links green spaces and axial lines). 


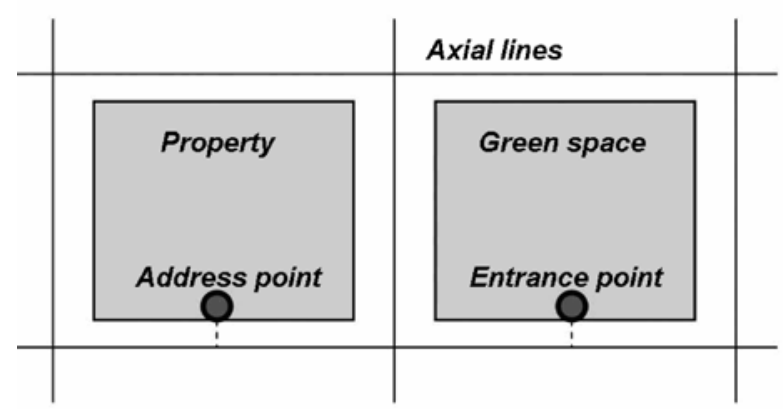

Figure 3. Geographical elements used in the Place Syntax Tool; starting (properties) and target regions (open spaces), connecting address/entrance points, and axial lines.

PST has opened a series of possible new accessibility analyses. In its theory, the Place Syntax model is based on standard accessibility models of contemporary GIS research. The accessibility (A) in the location $i$ is

$$
A_{i}=\sum f\left(W_{j}, d_{i j}\right),
$$

where $\mathrm{W}_{j}$ is a measure of the attraction at the locations $j$ and $\mathrm{d}_{i j}$ is a measure of distance from the location $i$ to the locations $j$. Based on this formula, many types of green space accessibility measures can be created. In the GIS-analyses presented below, $\mathrm{W}_{j}$ and $\mathrm{d}_{i j}$ are divided according to the theoretical framework described above. $\mathrm{W}_{j}$ is measured by green space surface area $(j)$, and the number of use values in every green space. $d_{i j}$ is measured by pedestrian distance in axial line steps (orientation) and in meters (range). In the GIS-analyses below, different variations of this accessibility formula are tested and correlated against empirical data. 


\section{Materials}

\subsection{Study areas}

The research project incorporates different urban and suburban areas within Stockholm municipality. The municipality basically organizes all socio-economical data and sociological surveys on 18 city districts (http://www.stockholm.se/usk). Ten study areas (Figure 4) - 100 hectares each (+- 0.1) - with four distinct types (Table 2) have been selected for more careful analysis; three $18^{\text {th }}$ century block grid areas, three post war modernist suburbs from around 1950, three garden city suburbs, and one post-modernist block grid area from 1980s. All study areas are quite homogeneous urban typo-morphologies as defined by the Stockholm City Plan from 1999 (Stockholms stad 1999). 


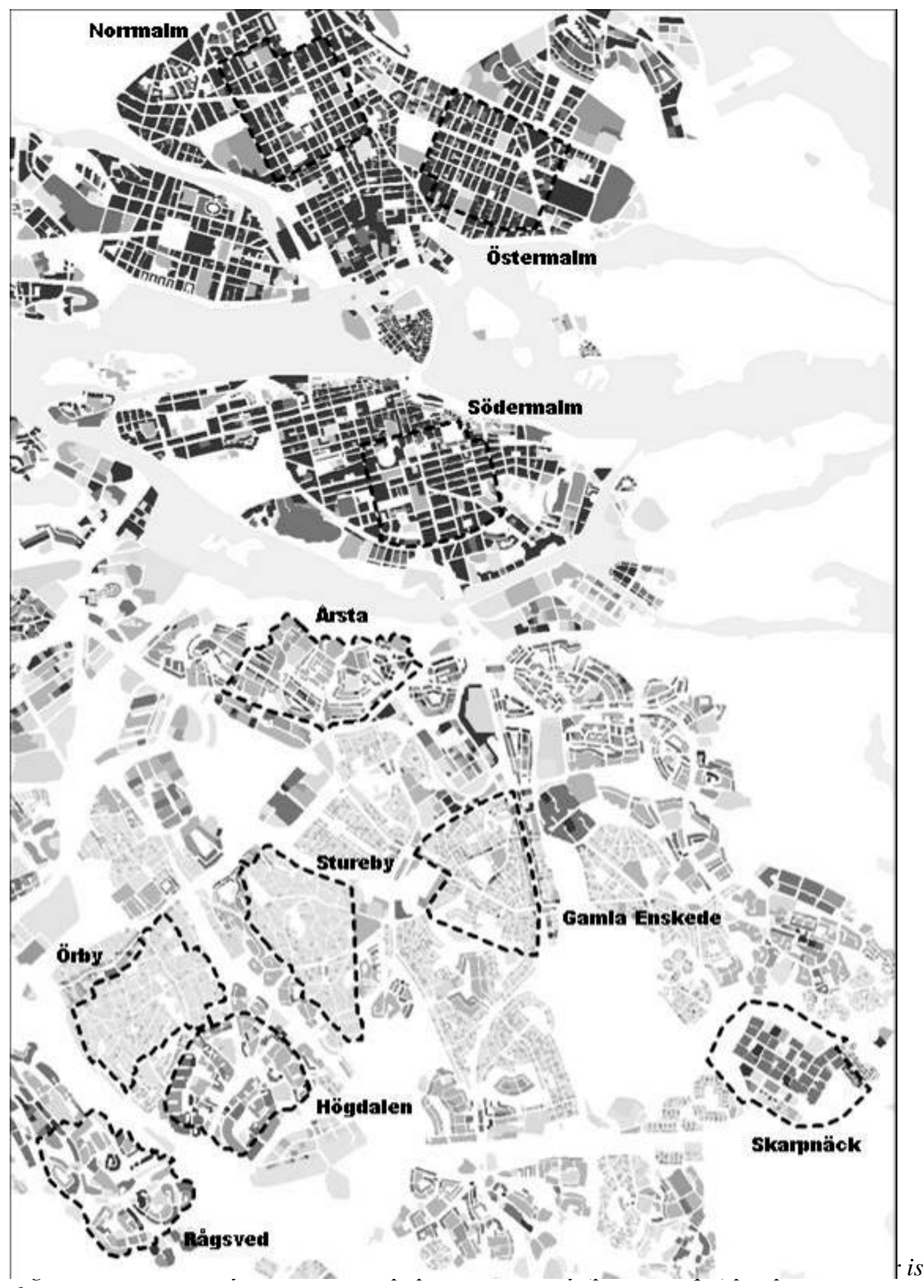

denser. 


\begin{tabular}{|l|l|l|}
\hline GRID CITY & MODERNIST CITY & GARDEN CITY \\
$\begin{array}{l}\text { "Urban, dens, enclosed blocks, } \\
\text { traditional, traffic integrated" }\end{array}$ & $\begin{array}{l}\text { "Suburban, dense, open, } \\
\text { green, traffic separated" }\end{array}$ & $\begin{array}{l}\text { "Suburban, sparse, open, green, } \\
\text { traditional, traffic integrated" }\end{array}$ \\
\hline Norrmalm & Rågsved & Örby \\
\hline Grid district (1600-1900) & Subway district (1956-59) & Villa district (1900-1930) \\
\hline Östermalm & Högdalen & Stureby \\
Grid district (1600-1900) & Subway district (1953-56) & Villa district (1920-1930) \\
\hline Södermalm & Årsta & Gamla Enskede \\
Grid district (1600-1900) & Lamella district (1943-50) & Garden district (1910-1930) \\
\hline \multicolumn{2}{|l|}{ Skarpnäck } & \\
\hline
\end{tabular}

design guide (Stockhölms byggnädsordning frö 1999).

\begin{tabular}{|l|c|c|c|c|c|c|c|}
\hline Study area & $\begin{array}{c}\text { Floor } \\
\text { Area } \\
\text { Ratio }\end{array}$ & $\begin{array}{c}\text { Total plot } \\
\text { surface } \\
\text { area (ha) }\end{array}$ & $\begin{array}{c}\text { Mean plot } \\
\text { area (ha) }\end{array}$ & $\begin{array}{c}\text { Number } \\
\text { of } \\
\text { properties }\end{array}$ & $\begin{array}{c}\text { Number } \\
\text { of } \\
\text { addresses }\end{array}$ & Number of & $\begin{array}{c}\text { Mean axial line } \\
\text { length (meter) }\end{array}$ \\
\hline Norrmalm & 2.24 & 64.29 & 0.10 & 632 & 1395 & 104 & 258.06 \\
\hline Östermalm & 2.18 & 67.41 & 0.10 & 695 & 1475 & 64 & 379.50 \\
\hline Södermalm & 2.03 & 60.18 & 0.13 & 481 & 1283 & 131 & 221.07 \\
\hline Skarpnäck & 0.45 & 40.22 & 0.40 & 100 & 519 & 280 & 111.25 \\
\hline Årsta & 0.50 & 54.23 & 0.25 & 216 & 770 & 296 & 108.53 \\
\hline Högdalen & 0.52 & 53.38 & 0.45 & 118 & 754 & 435 & 100.00 \\
\hline Rågsved & 0.44 & 51.91 & 0.46 & 112 & 519 & 337 & 102.88 \\
\hline GamlaEnskede & 0.19 & 57.25 & 0.06 & 956 & 1249 & 170 & 167.55 \\
\hline Stureby & 0.13 & 74.38 & 0.08 & 897 & 1098 & 143 & 162.05 \\
\hline Örby & 0.13 & 75.64 & 0.08 & 983 & 1186 & 134 & 168.87 \\
\hline
\end{tabular}

Table 3. Spatial data for the ten study areas. Highest values in grey. (www.uskab.se 2007) 


\begin{tabular}{|l|c|r|r|r|r|r|c|}
\hline Analysområde & $\begin{array}{c}\text { Residents } \\
\text { and workers }\end{array}$ & $\begin{array}{c}\% \\
\text { Residents }\end{array}$ & $\begin{array}{c}\text { Floor } \\
\text { area per } \\
\text { person }\end{array}$ & $\begin{array}{c}\text { Children } \\
0-12 \\
\text { years }\end{array}$ & $\begin{array}{c}\text { Income } \\
\text { level }\end{array}$ & $\begin{array}{c}\text { Educational } \\
\text { level }\end{array}$ & \% Voters \\
\hline Norrmalm & 40452 & $56 \%$ & 55,41 & 2410 & 310600 & 61,5 & 80,7 \\
\hline Östermalm & 37034 & $58 \%$ & 59,00 & 2166 & 362900 & 62,2 & 81,6 \\
\hline Södermalm & 39367 & $69 \%$ & 51,54 & 2911 & 264500 & 53,9 & 79,1 \\
\hline Skarpnäck & 9864 & $80 \%$ & 45,71 & 1442 & 216300 & 40,0 & 73,1 \\
\hline Årsta & 10234 & $84 \%$ & 49,05 & 790 & 247300 & 47,1 & 78,7 \\
\hline Högdalen & 10742 & $85 \%$ & 48,82 & 912 & 208900 & 29,8 & 71,5 \\
\hline Rågsved & 9579 & $93 \%$ & 45,70 & 1411 & 182400 & 27,1 & 61,9 \\
\hline Gamla Enskede & 4488 & $87 \%$ & 42,42 & 727 & 284100 & 54,6 & 75,6 \\
\hline Stureby & 2820 & $94 \%$ & 47,19 & 526 & 275000 & 48,7 & 78,5 \\
\hline Örby & 3040 & $93 \%$ & 43,45 & 568 & 300400 & 44,4 & 84,6 \\
\hline
\end{tabular}

The population density map and the table for spatial and social data (Table 3 and 4 ) show that Stockholm has been systematically planned and designed. The four city types are clearly visible in terms of 'Floor Area Ratio', 'Mean plot area', and 'Mean axial line length'. Notable is the 1980s postmodern grid in Skarpnäck, which has been said by municipal planners to be designed like the inner city grid at Östermalm (Figure 5), but looks in spatial figures more like a 1950s modernist suburb. 


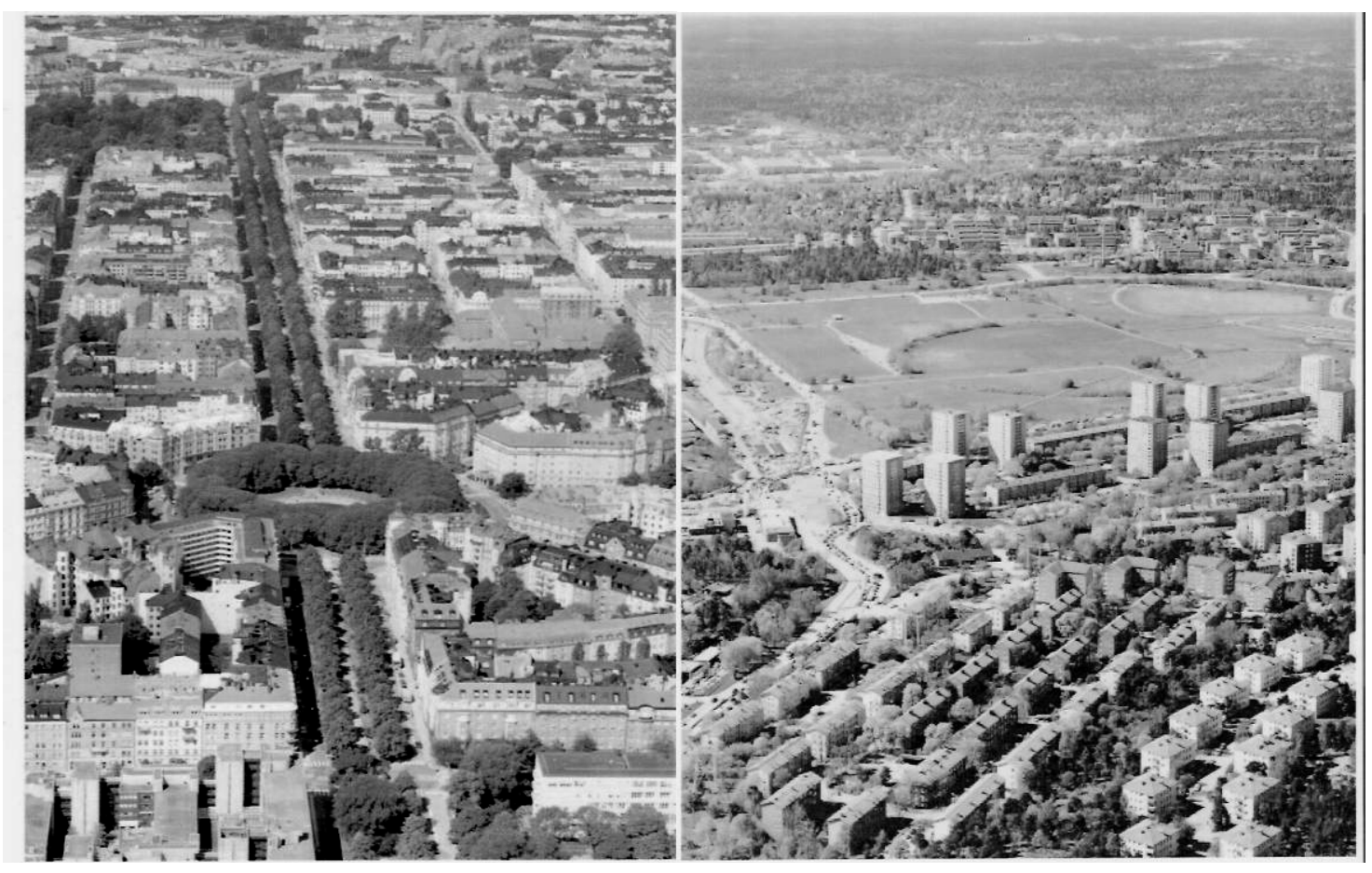

Figure 5. Inner city area of Östermalm - looking west towards Norrmalm (left image), and 1950s century suburbia of Årsta south of the inner city - looking south towards Stureby (right image)

\subsection{Empirical data}

Three sets of empirical data were used to capture how citizen's experiences were connected to green space: two questionnaires and one site observation study. These user surveys are later correlated to various GIS-analyses of green space accessibility.

\subsubsection{TEMO questionnaire 2001}

The first questionnaire is the most significant and basically the starting point of the research project (TEMO 2001). In 2001, a leading Swedish market research agency TEMO executed a questionnaire for citizens of the municipality of Stockholm. The questionnaire asked the participants this question: "Do you experience a lack of parks and nature areas in the vicinity of your home?” TEMO mailed 8740 questionnaires and agglomerated at the city district level. The stunning result (Figure 6) was that people in many of the inner city districts, and some denser suburbs, were experiencing less lack of green areas than some low-density "green” post-war suburbs. 


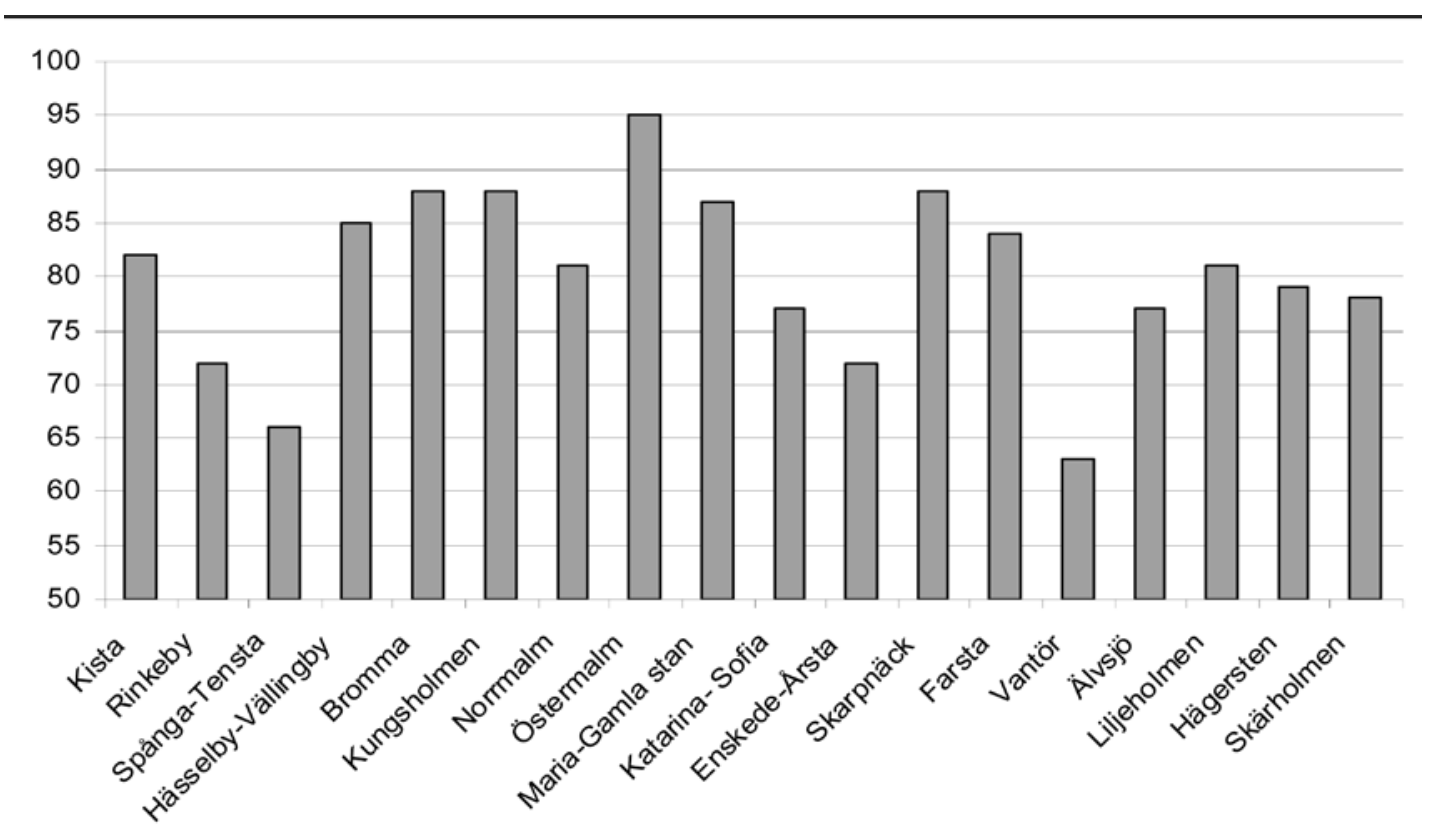

Figure 6. Percentage of people that do not experience a lack of parks and nature areas in the vicinity of their home for every city district within Stockholm municipality (TEMO 2001).

The answer frequency can be considered rather low: 54\%. TEMO, however, verifies the statistical significance of the results. The results were also confirmed in a recent study from 2004 conducted by Stockholm Office of Research and Statistics (USK 2004). In this questionnaire, which has an answer frequency of $67 \%$, this question was asked: "Are you satisfied/not satisfied with the supply of parks and nature areas in your city district?” The similarities (Figure 7) verify the results and evidently confirm the differences of people's experienced supply of or accessibility to green areas in the city districts.

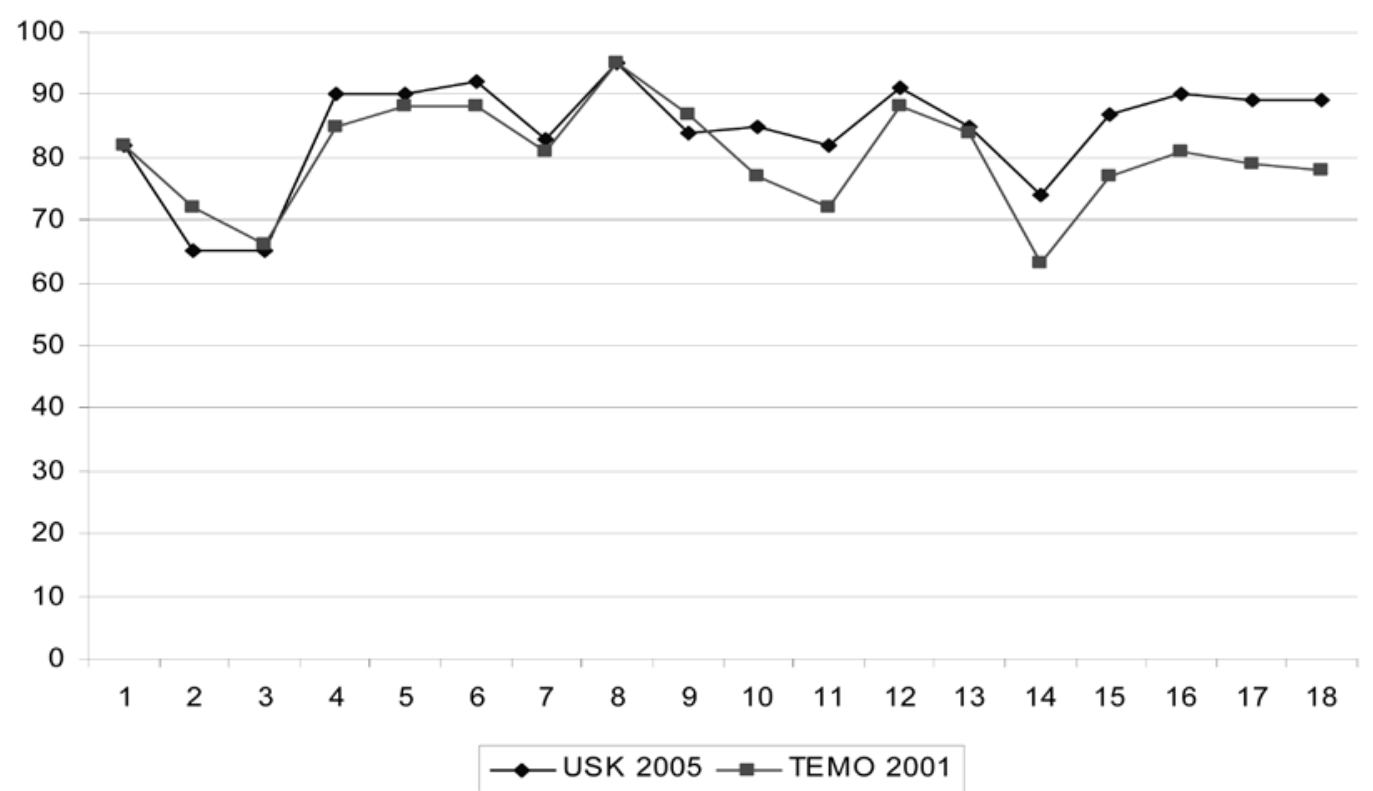


Figure 7. The similar results from the TEMO 2001 and USK 2004 questionnaires concerning the experience of green area accessibility.

City districts, however, are a bit too different in size and shape to use for correlation studies, so questionnaires from TEMO 2001 were sorted by zip codes for the ten study areas (Figure 8 and table 5).

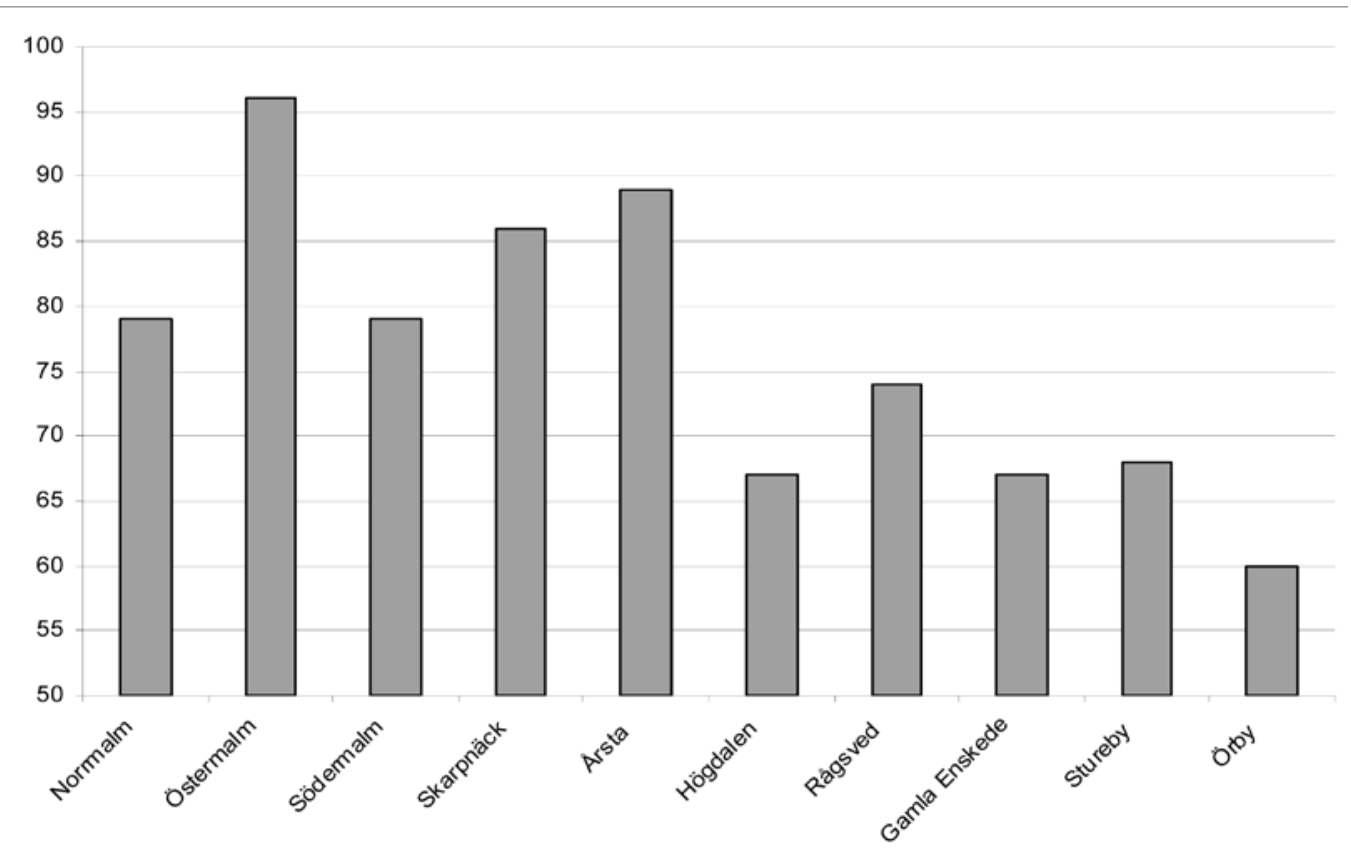

Figure 8. Percentage of people that do not experience a lack of parks and nature areas in the vicinity of their home for the ten study areas (TEMO 2001).

\begin{tabular}{|l|c|c|c|c|}
\hline Study area (City district) & $\begin{array}{c}\text { Number of } \\
\text { questionnaires }\end{array}$ & $\begin{array}{c}\text { \% of the } \\
\text { population }\end{array}$ & $\begin{array}{c}\text { Statistical } \\
\text { uncertainty }\end{array}$ & $\begin{array}{c}\text { \% that do not } \\
\text { experience lack of } \\
\text { green areas }\end{array}$ \\
\hline Norrmalm (Norrmalm) & 110 & 0.48 & +-8.7 & $79(70-88)$ \\
\hline Östermalm (Östermalm) & 100 & 0.47 & +-4.4 & $96(92-100)$ \\
\hline Södermalm (Södermalm) & 179 & 0.66 & +-8.7 & $79(70-88)$ \\
\hline Skarpnäck (Skarpnäck) & 44 & 0.56 & +-13.0 & $86(73-99)$ \\
\hline Årsta (Enskaede-Årsta) & 79 & 0.92 & +-8.2 & $89(81-97)$ \\
\hline Högdalen (Vantör) & 81 & 0.89 & +-11.0 & $67(56-78)$ \\
\hline Rågsved (Vantör) & 49 & 0.55 & +-13.0 & $74(61-87)$ \\
\hline
\end{tabular}




\begin{tabular}{|l|c|c|c|c|}
\hline Gamla Enskede (E.-Årsta) & 24 & 0.61 & +-16.7 & $67(50-84)$ \\
\hline Stureby (Enskede-Årsta) & 34 & 1.28 & +-17.4 & 68 (51-85) \\
\hline Örby (Vantör) & 47 & 1.66 & +-17.9 & $60(42-88)$ \\
\hline & 747 & & & \\
& & & & \\
\hline
\end{tabular}

Table 5. The statistics on the TEMO 2001 questionnaire for the ten study areas.

Some objections can be identified. How do people understand the concept "parks and nature areas"? Is not there a different demand for green areas between different areas? These objections are nonetheless hypothetical. Contemporary research has not found any statistical differences in the demand for public green areas between different city districts, between suburbs and inner city cores. The demand seems to differ for private green space, but not for public green areas. (Grahn \& Stigsdotter 2003) At the city district level, the visiting frequency experienced in green area in the USK questionnaire from 2002 seems to confirm the results above.

\subsubsection{USK questionnaire 2002}

The USK questionnaire from 2002 was sent out to 5400 households and included the question "How often do you visit your favourite park/nature area?" (Figure 9).

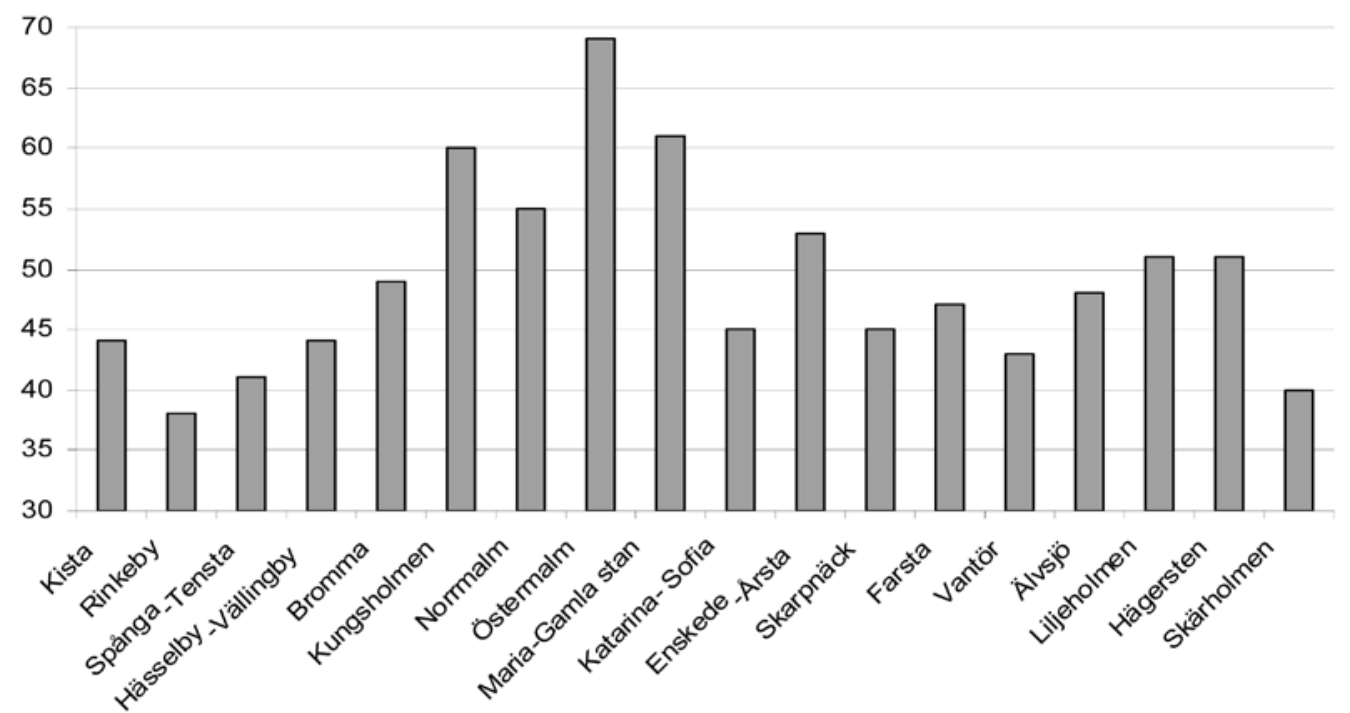

Figure 9. Percent of the respondents that go to their favourite green area daily or once a week. The diagram shows all city districts within Stockholm municipality. (USK 2002) 
In this questionnaire, it is just as a surprising result as for the TEMO survey. People in the inner city and in the garden suburbs visit public green areas more often than the late modernist areas. This questionnaire has not been possible to sort by zip codes.

\subsubsection{On-site observations in spring 2004}

Between the $15^{\text {th }}$ April and $30^{\text {th }}$ May 2004, landscape architect Anders Sandberg executed onsite observations and visit counts in eleven parks (Figure 10), five in the inner city (Östermalm and Norrmalm) and six in modernist suburbs from the 1950s (Högdalen and Rågsved).

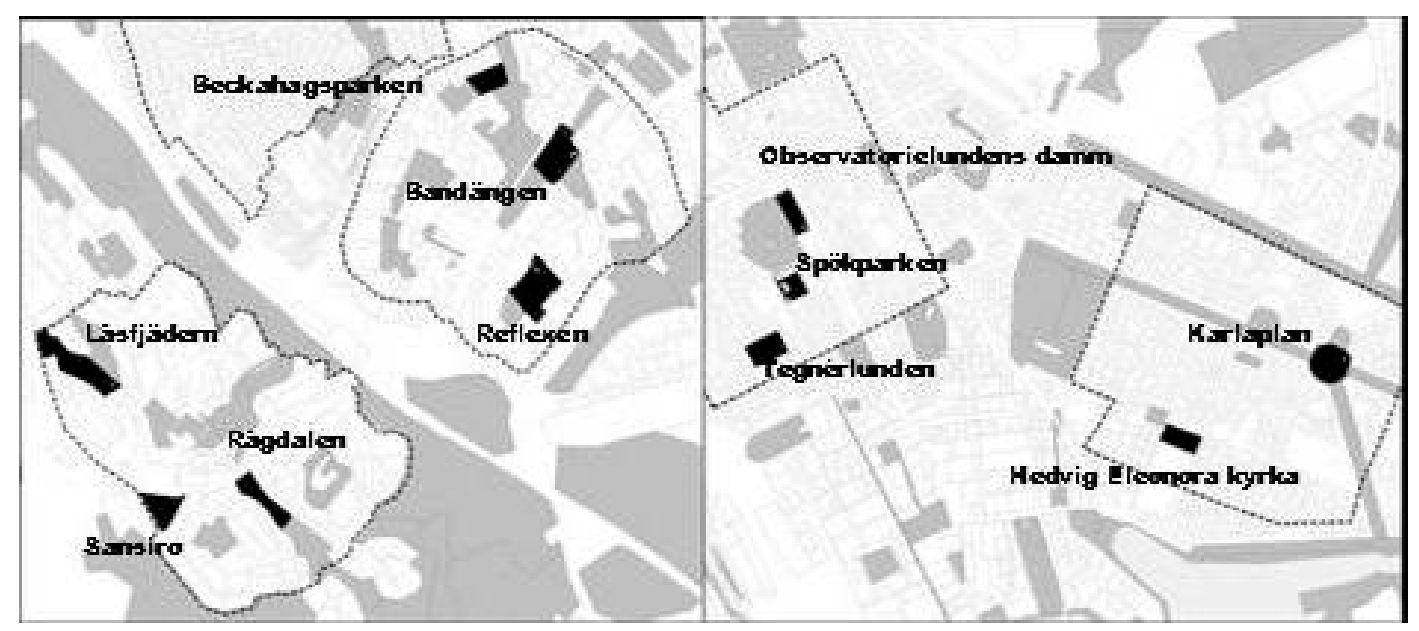

Figure 10. Parks where on-site observation and visit counts where executed.

The parks are 1-2.5 hectares and have some differences in composition of use values. Number of staying and passing visitors were counted as a "snap shot" during a 10-minute period. The small park size made it possible to overlook the whole green space. 


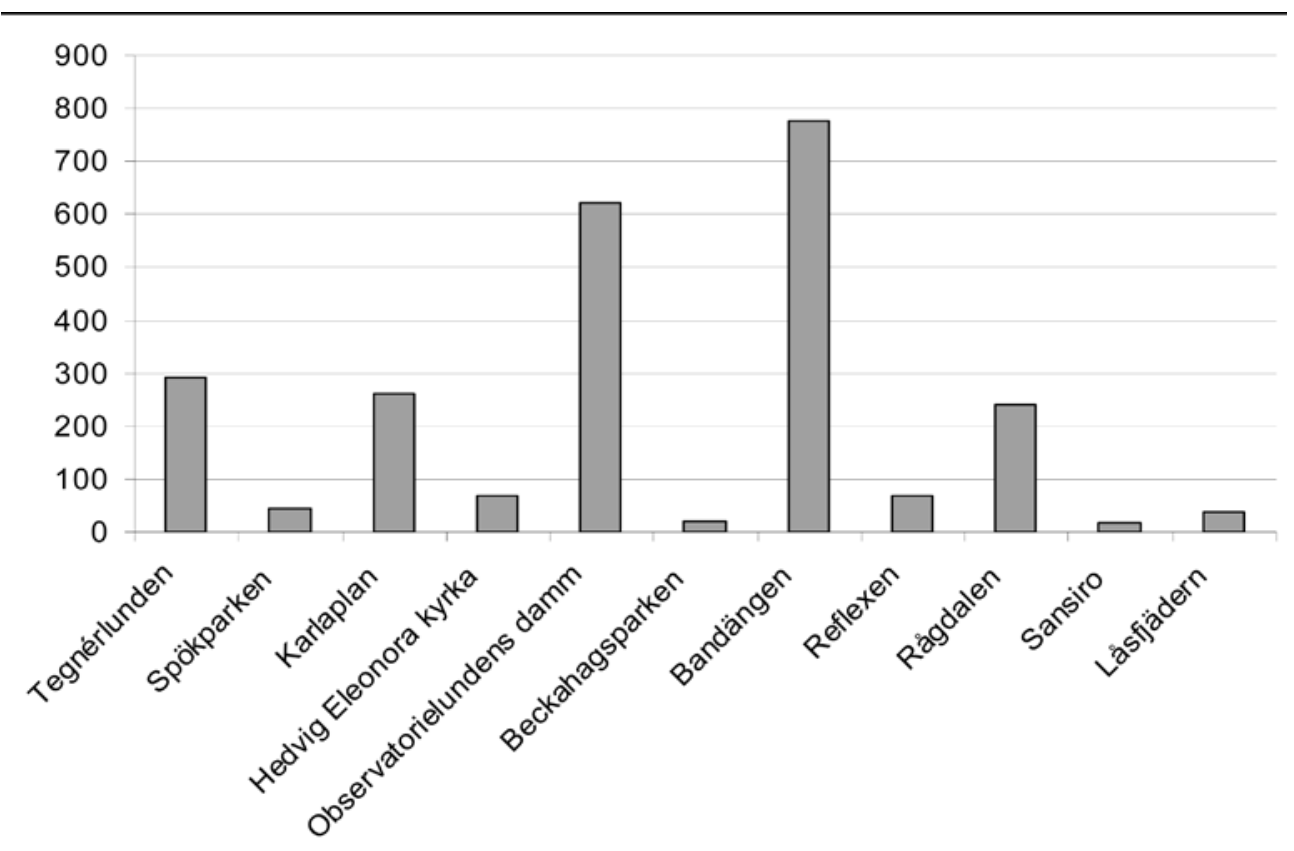

Figure 11. The total number of staying visitors during the time of observation in all parks.

The number of visitors (Figure 11) indicates that green space size cannot be the singular explanation of attraction. Use value composition together with accessibility and urban density play a central part in attraction and actual use. 


\section{Results}

The purpose of the GIS-analyses was to test conventional and new green space measures against the empirical data. At first, it is just interesting to theoretically compare the different GIS-results, but in the end the real question is this: How well do old and new measures capture people's life world and experience?

\subsection{Conventional measures and guidelines}

In this section, conventional green space surface area measures and green space guidelines are executed for the study areas. The first basic analysis of an area is how much of it is covered by green space. The numbers in Table 6 are in hectares, but they also show the percentage because the study areas are all 100 hectares each.

\begin{tabular}{|l|l|l|l|l|l|}
\hline Study area & Un-built land & $\begin{array}{l}\text { Green } \\
\text { biotope }\end{array}$ & $\begin{array}{l}\text { Municipal green } \\
\text { space } \\
\text { (naturmark + } \\
\text { parkmark) }\end{array}$ & $\begin{array}{l}\text { Municipal natural } \\
\text { green } \\
\text { (naturmark) }\end{array}$ & $\begin{array}{l}\text { Public green space } \\
\text { (sociotope) }\end{array}$ \\
\hline Norrmalm & 83.54 & 10.33 & 8.22 & 0.97 & 9.50 \\
\hline Östermalm & 81.43 & 7.28 & 4.37 & 0.00 & 10.34 \\
\hline Södermalm & 84.43 & 12.19 & 13.24 & 0.47 & 17.85 \\
\hline Skarpnäck & 92.89 & 48.77 & 47.71 & 18.90 & 41.27 \\
\hline Årsta & 93.68 & 52.46 & 32.42 & 21.83 & 20.88 \\
\hline Högdalen & 93.27 & 34.55 & 28.32 & 11.37 & 22.44 \\
\hline Rågsved & 94.72 & 38.65 & 31.87 & 17.23 & 19.42 \\
\hline Gamla Enskede & 95.66 & 66.42 & 27.43 & 6.57 & 19.22 \\
\hline Örby & 95.06 & 58.75 & 9.80 & 10.10 & 7.25 \\
\hline
\end{tabular}

Table 6. Surface area of green and open space in hectares in the study areas. Highest values in grey.

The results above are not surprising from the common (planner or developers) point of view of these city districts. The inner city areas have consequently lower green space coverage, and 
the suburb areas have considerably higher. When these numbers are divided with the area population, the differences increased significantly.

Turning to more advanced measures and recently developed guidelines, yet based on conventional measurements of surface area and metric distance, the National Board of Housing, Building and Planning (Boverket 1999) published common guidelines on green space accessibility (Table 7) based on earlier recommendations from the Nordic Council of Ministers.

\begin{tabular}{|l|c|l|l|}
\hline $\begin{array}{l}\text { Green space } \\
\text { type }\end{array}$ & Min. size & Max. distance & \multicolumn{1}{|c|}{ Specifications } \\
\hline Pocket parks & - & $<50$ meter & Green space \\
\hline Local parks & $>0,3-0,6$ ha & $<200$ meter & Green space, play area \\
\hline District parks & $>10-20$ ha & $<500-800$ meter & Green space, play area, peace \& quite, recreational activities \\
\hline Nature areas & $>1000$ ha & $(<1000$ meter $)$ & Wilderness, play area, peace \& quite, recreational activities \\
\hline
\end{tabular}

Table 7. National open space guidelines by Boverket from 1999.

In 2004, Stockholm municipality published the Stockholm park program, a policy for the development and maintenance of municipal green areas (Table 8). In this document, guidelines were developed from the national recommendations, but locally fitted.

\begin{tabular}{|l|l|l|l|}
\hline $\begin{array}{l}\text { Green space } \\
\text { type }\end{array}$ & Min. size & Max. distance & \multicolumn{1}{|c|}{ Specifications } \\
\hline Local parks & $\mathbf{0 , 5 - 5}$ ha & $<200$ meter & Green space, play area \\
\hline District parks & $\mathbf{5 - 5 0 ~ h a}$ & $<500$ meter & Green space, play area, peace \& quite, recreational activities \\
\hline Nature areas & $>\mathbf{5 0 ~ h a}$ & $<1000$ meter & Wilderness, play area, peace \& quite, recreational activities \\
\hline
\end{tabular}

Table 8. Municipal open space guidelines in the Stockholm park program from 2005.

Table 9 shows the proportion of the population in the study areas that fulfil the guidelines. Distance has been measured as conventional bird's distance, and the sociotope map has been used to select type of green areas.

\begin{tabular}{|l|c|c|c|c|c|c|c|}
\hline & Boverket0 & Boverket1 & Stockholm1 & Boverket2 & Stockholm2 & Boverket3 & Stockholm3 \\
Study area & $0.5 \mathrm{ha}$ & $0.5 \mathrm{ha}$ & $0.5 \mathrm{ha}$ & $10 \mathrm{ha}$ & $5 \mathrm{ha}$ & $100 \mathrm{ha}$ & $50 \mathrm{ha}$ \\
& $50 \mathrm{~m}$ & $200 \mathrm{~m}$ & $200 \mathrm{~m}$ & $500 \mathrm{~m}$ & $500 \mathrm{~m}$ & $1000 \mathrm{~m}$ & $1000 \mathrm{~m}$ \\
\hline Norrmalm & 20.28 & 90.43 & 90.43 & 13.87 & 100 & 21.06 & 21.06 \\
\hline
\end{tabular}




\begin{tabular}{|l|c|c|c|c|c|c|c|}
\hline Östermalm & 29.92 & 92.48 & 92.48 & 50.55 & 87.72 & 49.56 & 49.56 \\
\hline Södermalm & 31.18 & 92.60 & 92.60 & 33.30 & 39.34 & 0 & 0 \\
\hline Skarpnäck & 42.78 & 92.13 & 92.13 & 100 & 100 & 100 & 100 \\
\hline Årsta & 46.98 & 99.60 & 99.60 & 99.30 & 100 & 100 & 100 \\
\hline Högdalen & 53.39 & 100 & 100 & 56.20 & 93.82 & 50.85 & 89.88 \\
\hline Rågsved & 53.87 & 100 & 100 & 88.05 & 100 & 76.86 & 100 \\
\hline $\begin{array}{l}\text { Gamla } \\
\text { Enskede }\end{array}$ & 37.12 & 86.79 & 86.79 & 70.61 & 71.01 & 22.64 & 80.28 \\
\hline Stureby & 21.70 & 89.29 & 89.29 & 95.99 & 95.99 & 65.00 & 96.88 \\
\hline Örby & 19.51 & 73.82 & 73.82 & 57.63 & 99.84 & 5.46 & 6.81 \\
\hline
\end{tabular}

Table 9. Proportion of the population within the study areas that fulfil the national (Boverket) and municipal (Stockholm) guidelines. Highest values in grey.

Columns Boverket2 and Stockholm2 show how the Stockholm guidelines catch local qualities. Many things can be said about these results, but this example shows that it is not unproblematic to put green areas of 4.9 and 5.1 hectares in different classes and 0.5 and 4.9 in the same class. The critical question is still this: Do these numbers correlate with people's need and demand for urban public green areas? The findings presented in this paper indicate that they do not.

\subsection{Green space accessibility analyses}

Three types of green space accessibility analyses were extensively tested: green space proximity, green space accessibility, and green space/population accessibility.

\begin{tabular}{|c|c|c|c|c|c|c|c|c|}
\hline Study area & $\begin{array}{l}\text { "Bird's } \\
\text { distance" } \\
\text { to green } \\
\text { space }\end{array}$ & $\begin{array}{c}\text { Walk } \\
\text { distanc } \\
\text { e to } \\
\text { green } \\
\text { space }\end{array}$ & $\begin{array}{c}\text { Axial } \\
\text { line } \\
\text { distanc } \\
\text { e to } \\
\text { green } \\
\text { space }\end{array}$ & $\begin{array}{c}\text { Green } \\
\text { space } \\
\text { within } \\
500 m \\
\text { bird's d. }\end{array}$ & $\begin{array}{l}\text { Green } \\
\text { space } \\
\text { within } \\
500 \mathrm{~m} \\
\text { walk d. }\end{array}$ & $\begin{array}{c}\text { Green } \\
\text { space } \\
\text { within } \\
3 \text { axial } \\
\text { steps }\end{array}$ & $\begin{array}{l}\text { Comb- } \\
\text { ined }\end{array}$ & $\begin{array}{c}\text { Accessible } \\
\text { green } \\
\text { space/pers }\end{array}$ \\
\hline Norrmalm & 141.67 & 199.33 & 1.96 & 10.55 & 28.23 & 79.49 & 148.84 & 13.74 \\
\hline Östermalm & 120.31 & 152.63 & 1.54 & 12.97 & 41.10 & 102.61 & & 31.11 \\
\hline Södermalm & 105.32 & 157.80 & 1.80 & 13.79 & 36.10 & 48.91 & & 19.00 \\
\hline
\end{tabular}




\begin{tabular}{|c|c|c|c|c|c|c|c|}
\hline Skarpnäck & 107.82 & 169.76 & 2.90 & 27.81 & 49.00 & 14.85 & 228.21 \\
\hline Årsta & 107.62 & 159.40 & 2.78 & 22.81 & 45.38 & 11.17 & 172.80 \\
\hline Högdalen & 87.51 & 154.91 & 3.29 & 19.08 & 35.92 & 3.54 & 150.89 \\
\hline Rågsved & 102.27 & 160.92 & 3.08 & 23.88 & 46.71 & 4.02 & 218.68 \\
\hline Gamla Enskede & 125.48 & 182.33 & 2.45 & 16.41 & 36.30 & 22.96 & 260.70 \\
\hline Stureby & 164.43 & 232.11 & 2.94 & 12.90 & 26.37 & 10.89 & 249.07 \\
\hline Örby & 196.59 & 325.08 & 3.06 & 10.45 & 11.25 & 3.19 & 101.83 \\
\hline
\end{tabular}

Table 10. Examples of green space accessibility measures. Columns 1-3 show green space proximity; 4-6 show green space accessibility; 7 shows a combined measure; and 8 shows green space/population accessibility. More explanation in the text below.

Table 10 shows examples of the analyses that where tested with PST. Column 1 shows "bird's distance" (straight-line distance or 'as-the-crow-flies') to the nearest public green area from every address point within the study area. Column 2 shows the true walk distance. Column 3 shows the axial step distance. Column 4 shows how much public green surface area that is accessible within 500 meters 'bird's distance', i.e., a 500-meter radius. Column 5 shows this within 500-meter true walk distance. Column 6 shows this within 3 axial steps. 


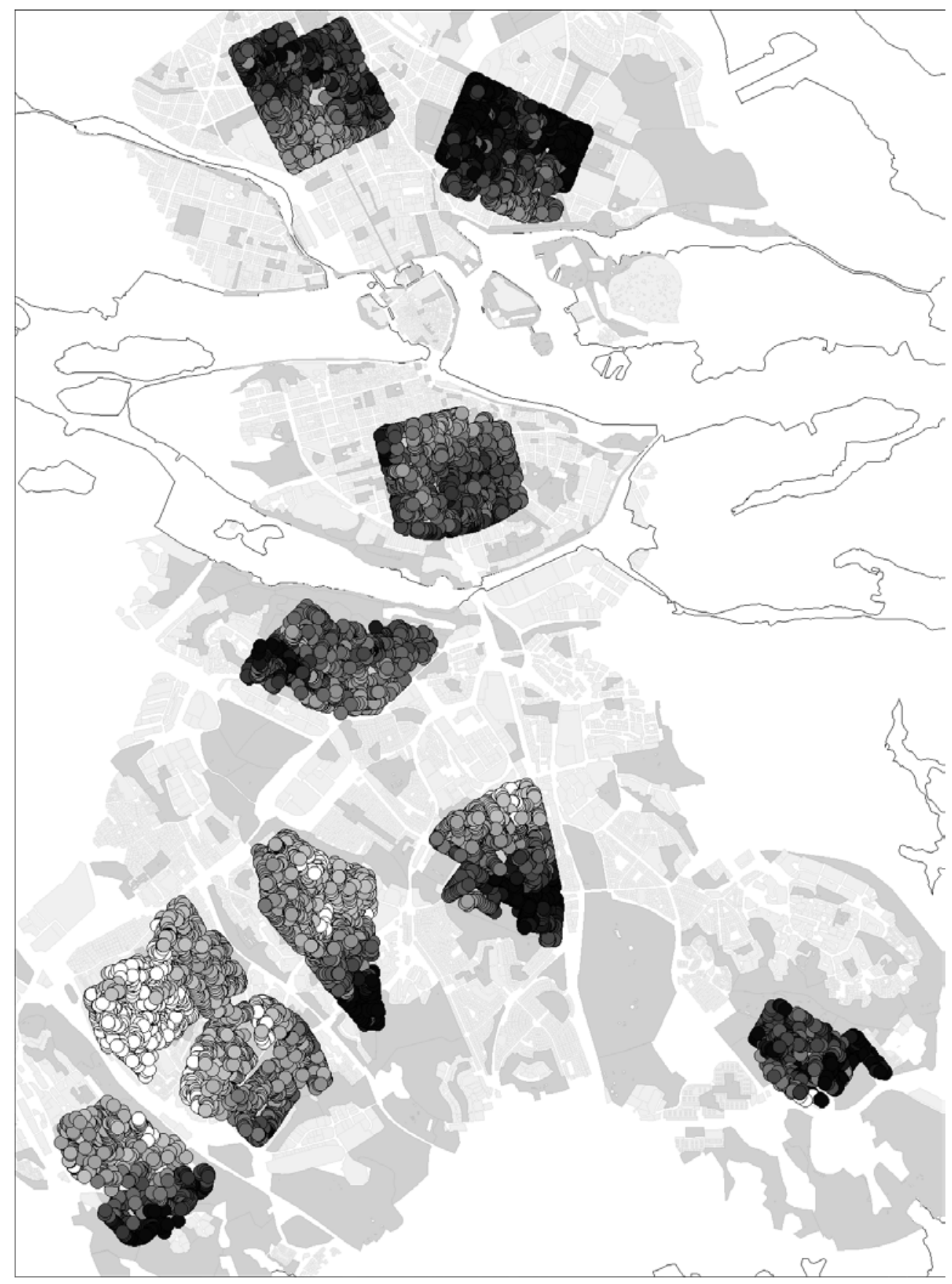

Figure 12. The combined measure (column 7) calculated and presented per address point within the study areas. Darker means higher green space accessibility. This measure had the best correlation with the TEMO 2001 questionnaire "Do you experience a lack of parks and nature areas in the vicinity of your home?"

Column 7 is a combined measure (Figure 12) that is constructed from the place syntax model described above. This measure calculates the accessible green surface area multiplied with the number of use values (from the sociotope map) as a measure of attraction. Every green area is also weighted depending on axial line distance from every address point. This means that each axial step away means half the green area. In this measure, a pedestrian range has been set to 1000 meters; i.e., green areas more than 1000 meters away are not calculated. The last 
column shows a value where the combined measure has been divided with the accessible population from every address point. Accessible population is calculated with the same formula as the combined measure. The correlation studies presented in the next section show that result columns 3 and 7 are the most empirically interesting.

\subsection{Axial line integration analysis}

The most common Space syntax analysis, axial line integration, was executed for all study areas (Figure 13) to study how spatially integrated the green areas were in the urban grid as a whole.

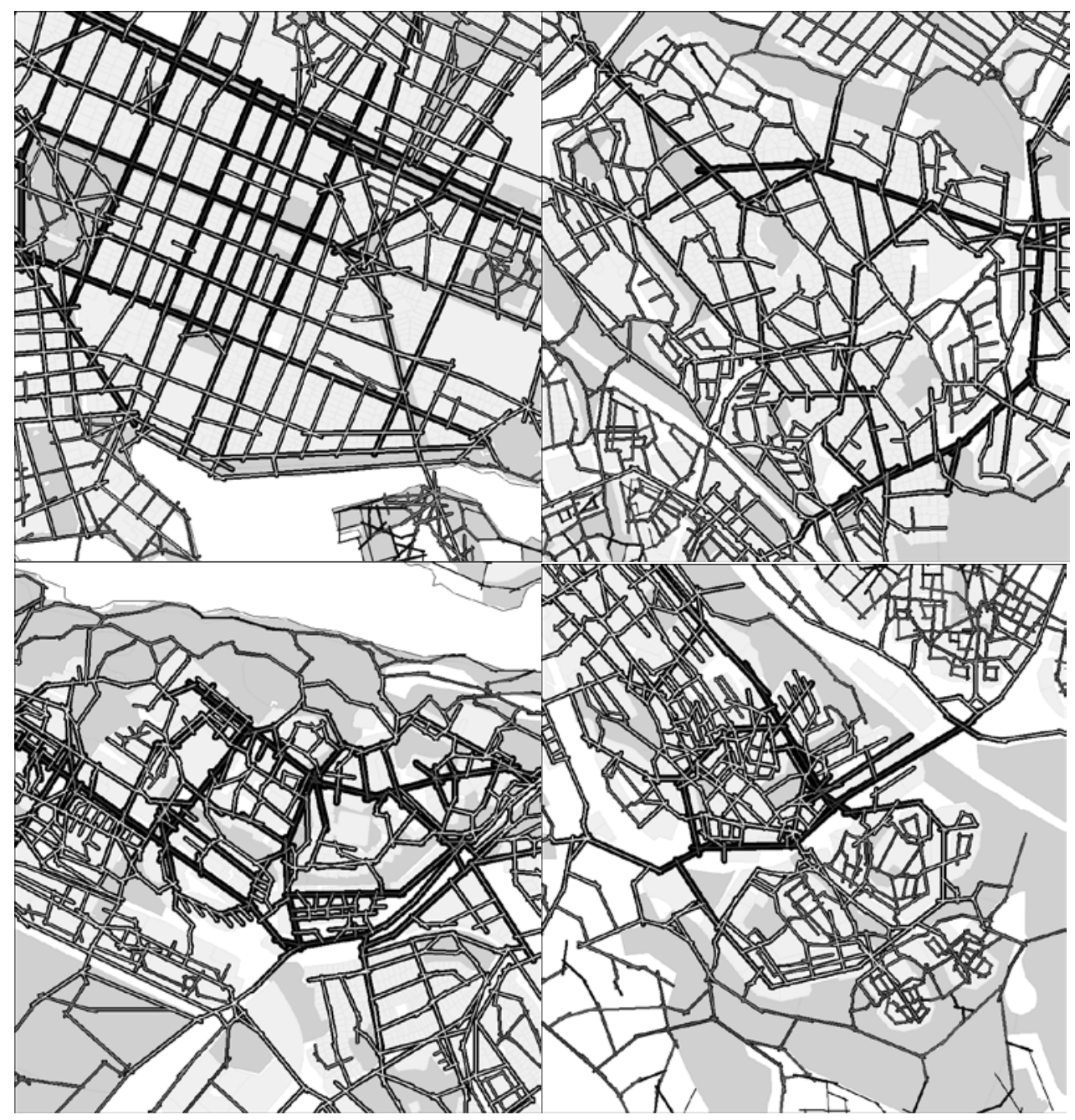

Figure 13. Global axial line integration (Space syntax measure) for four of the ten study areas. (wider is higher integration value). Östermalm - inner city grid (upper left), Stureby garden suburb (upper right), Arsta - early 1950s suburb (lower left), Rågsved - late 1950s suburb (lower right). 
The axial line integration analysis says something fundamental about the spatial integration of public open and green spaces. Integrated spaces will, according to the theory of natural movement (Hillier 1996, Hillier et al. 1996), play a more central role in the city's social life. These spaces will not only be more frequently visited and used, they will also probably get better known because they are located in more legible places and at the same time within the people's daily movement patterns. As shown in the integration maps above public green spaces are fully integrated in the $18^{\text {th }}$ inner city grid, partly integrated in the garden city suburb and mostly segregated in the modernist suburbs from the 1950ies. In many ways, these analysis results pinpoint the following findings and conclusions.

\subsection{Findings and correlations}

The major findings of this study are correlations. Some green space accessibility measures have been found to correlate with empirical data from questionnaires and observations.

\subsubsection{Measured and experienced green space accessibility}

The questionnaire from 2001 (TEMO) that asked "Do you experience a lack of parks and nature areas in the vicinity of your home?" was found to correlate, after extensive testing of many different open and green space accessibility measures, with the 'combined measure' presented in the former chapter. This measure calculates; accessible green surface area multiplied with its number of use values; it weights green areas according to axial line distance (one axial step away means half the green space), but limits pedestrian range to 1000 meters. The correlation is significantly high, $\mathrm{R}^{2}=0.74(\mathrm{p}<0.001)$ for all study areas (Figure 14). If two of the study areas are taken away, Årsta and Gamla Enskede, the correlation increases to $\mathrm{R}^{2}=0.98(\mathrm{p}<0.001)$. The intriguing thing is that correlations for any other conventional measures (green space sqm/pers) or guidelines (Boverket or Stockholm park program) was only $\mathrm{R}^{2}=0.02-0.22$.

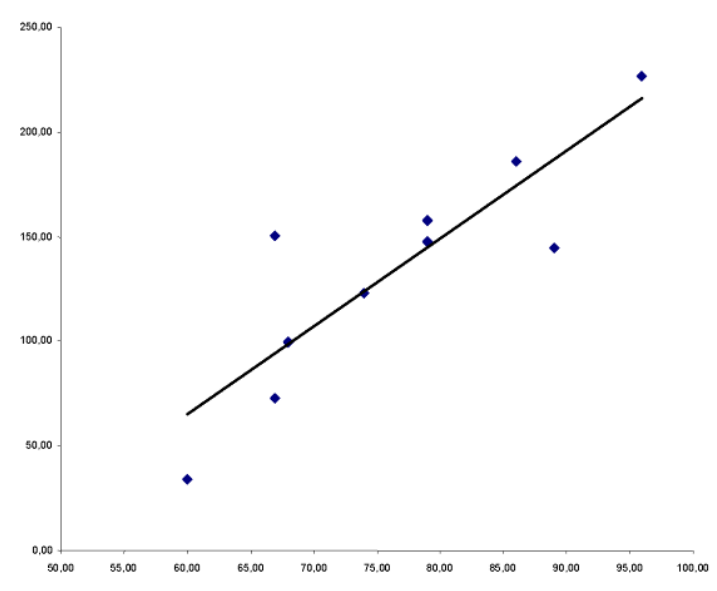

Figure 14. Correlation $R^{2}=0.74$ ( $\left.p<0,001\right)$ between how many, according to the TEM0 (2001) questionnaire, that do not experience a lack of parks and nature areas, and the combined measure of green space accessibility for the ten study areas. 
The principal finding from this correlation is that four major factors seem to highly affect green space accessibility: surface area, use values, orientation, and range. The result implies that if they all are systematically measured in GIS, it means this is a new useful tool for urban structure analysis and design. The results point out that the dense inner city areas with relatively low green and open surface area experiences measure higher accessibility than the two post-war suburbs, which have many times higher green and open surface area. Hence there exists 'more green space (in the life world of people), but denser cities (in the system world of planners)'. The explanation is, of course, the differences in use value and accessibility.

The results clearly imply that there are structural deficiencies in the post-war areas. This can be described as a green space structure efficiency ratio, which means dividing the combined measure with green space accessibility 1000-meter bird's distance.

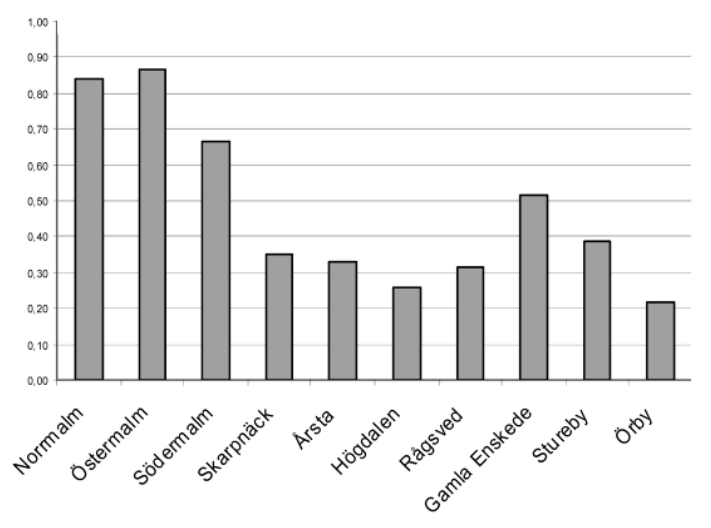

Figure 15. Green space structure efficiency for the ten study areas.

Figure 15 illustrates that the inner city grid more effectively distributes its green spaces to its inhabitants than the modernist tree-like morphologies of the suburbs. The best suburb, Gamla Enskede garden city area (urban design inspired by Unwin and Howard), is the only suburb that in some ways is like the inner city structure. If one looks at Östermalm, the best study area, it is systematically planned according to the Swedish late $19^{\text {th }}$ century regularist Albert Lindhagen, who was inspired by Haussmann in Paris among others. Lindhagen claimed that "the parks should be in everyone's way". The results show efficient park planning schemes (Figure 16) in Östermalm, schemes that look basically like a matrix of continuous street grids in which a connected green structure is integrated. The green structure consists of urban parks, which are interconnected by 40 -meter wide green esplanades. These esplanades also lead to the larger park and nature areas - the so called "green wedges". The consequence of this urban morphology is that you can see green space from any street in the district, and with some experience a citizen knows that this green space is part of the larger continuous green structure linked to the majors nature areas of the city. 

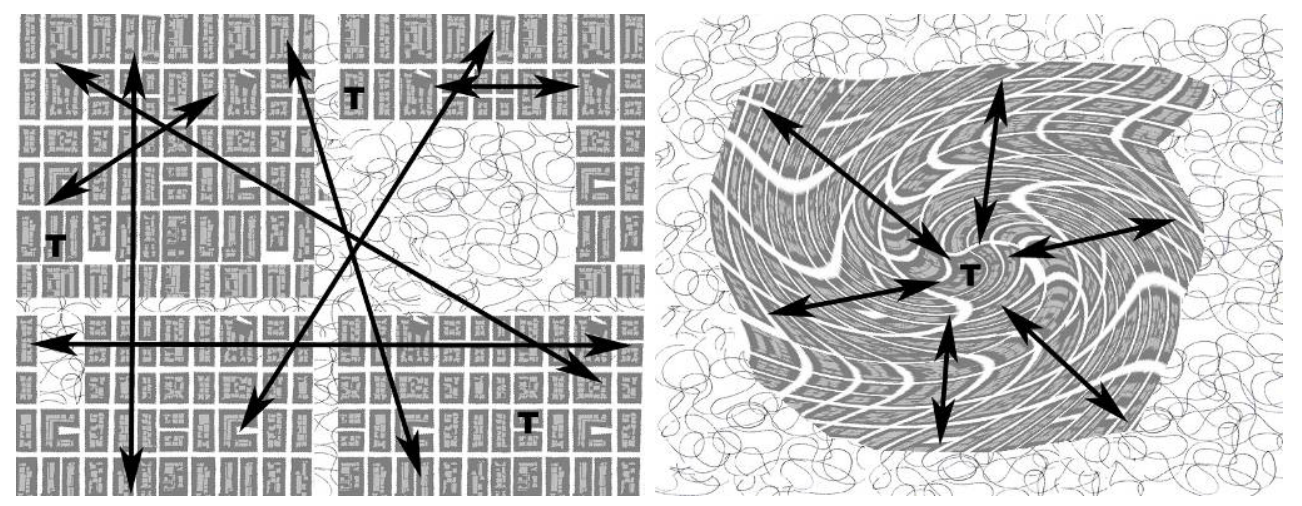

Figure 16. Principal schemes of the traffic integrated inner city grid with an integrated and continuous green structure (left) and of the post-war suburb with a surrounding greenbelt and an tree-like street grid with vehicular and pedestrian traffic separated (right). Arrows show principally daily movement patterns.

In the post-war suburbs, the main green structure is basically segregated around the settlement as green belts separating different suburbs all according to the park planning principles of the Stockholm general plan from 1952. These principles primarily origins from the municipal park officer Holger Blom (1938-71), who took much of these ideas from Frederick Law Olmsted's principle of having parkways and "an emerald necklace" around new towns. Firstly, this urban design concept does not seem as effective, in terms of land use, as the regularist concepts, when looking from a life world point of view. Secondly, these modernist principles have also created un-equitable distribution of green space stakeholders, as shown in the next section.

\subsubsection{Green space proximity and perceived visit frequency}

The USK questionnaire "How often do you visit your favourite park/nature area?" was correlating with axial line proximity to nearest green space (Figure 17), $\mathrm{R}^{2}=0.56(\mathrm{p}=0.018)$, but also with public green space area within five axial lines, $\mathrm{R}^{2}=0.77(\mathrm{p}=0.018)$.
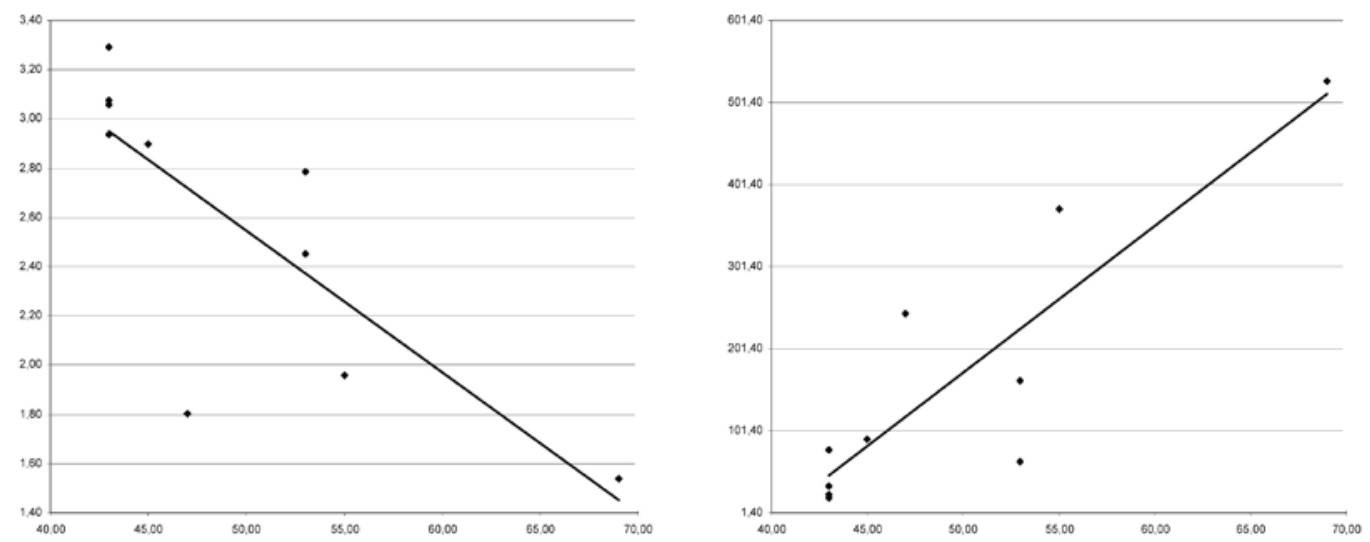

Figure 17. Correlation between how many who say that they visit their favourite park or nature area at least once a week and 1) axial line distance to the nearest public green area $R^{2}=-0,56, \mathrm{p}=0,018$, and 2) public green space surface area within five axial lines, $R^{2}=0,77$ $(\mathrm{p}=0,018)$. 
These correlations were not done on a study area level, but on a city district level. Study areas were defined from homogeneous urban morphology, but city districts are administrative areas and much more heterogeneous structures of different sizes and shapes. Therefore, these correlations are not as credible as the earlier one. Still they are very clear on one thing. Axial line distance, orientation, seems to be an important part of the explanation to why and how often people visit urban green areas. This conclusion is also confirmed by the Space syntax axial line integration analysis, which shows that green areas in the inner city grid are much more spatially integrated than in the post-war suburbs.

\subsubsection{Green space attraction, occupation, and spatial integration}

The on-site observations show that the selected inner city parks have more visitors than the selected 1950s parks. This is not so surprising compared to the area population densities. When the parks were divided into two groups (inner city parks and 1950s parks), correlations were found within the inner city parks between the number of use values and the number of staying visitors (not passers-through), $\mathrm{R}^{2}=0.83(\mathrm{p}=0.03)$. The same relation was not found to correlate at all in the 1950s parks, $\mathrm{R}^{2}=0.05(\mathrm{p}=0.686)$. (Figure 18)
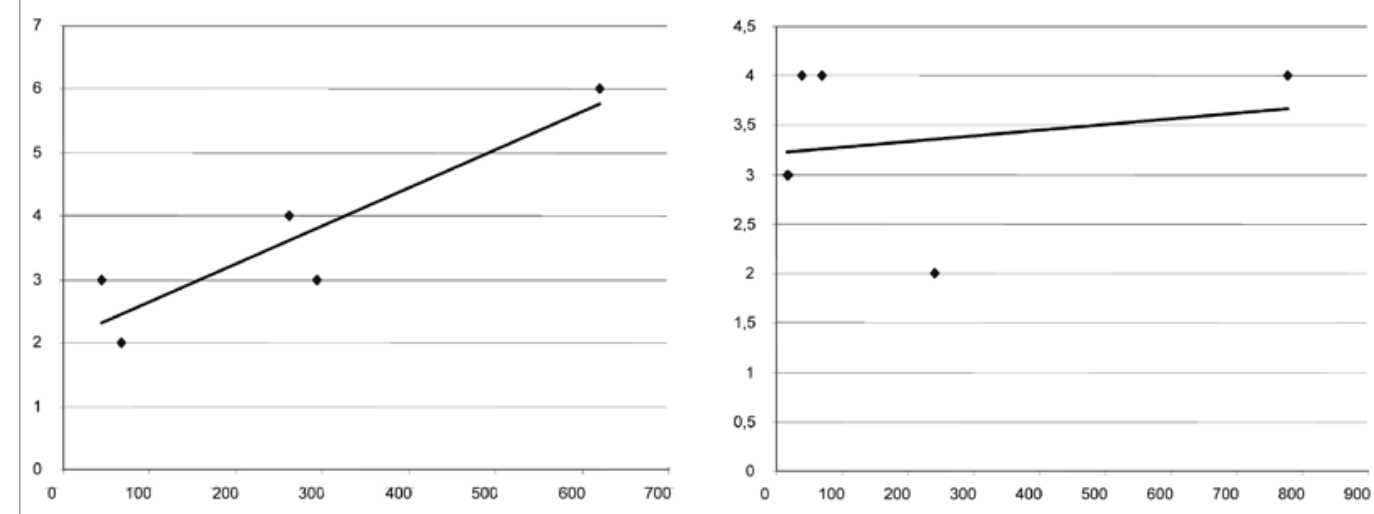

Figure 18. Correlation between the number of staying visitors and the number of use values in the inner city parks $\mathrm{R}^{2}=0.83, \mathrm{p}=0.03$ (left) and the 1950 s parks $\mathrm{R}^{2}=0.05, \mathrm{p}=0.686$ (right).

The conclusion of these results is similarly to the two earlier findings that the high spatial integration of the inner city parks means that they are probably appropriated more frequently. They are within the daily natural movement patterns, but they are also "marketing" themselves to the citizens because they are highly visible. Hence, the post-war parks are maybe not appropriated according to their attraction because of low spatial integration and legibility. This have to be further investigated to be confirmed. 


\section{Discussion and conclusions}

This paper has presented three major findings. The first is that a combined quantitative measure of green area size, number of use values, axial line distance, and 1000-meter pedestrian range can indicate the perceived green space accessibility in an urban area. Calculations for ten study areas of different urban morphologies, 100 hectares each, correlated better than any conventional measure or guidelines. These calculations were developed from the questionnaire asking "Do you experience a lack of parks and nature areas in your vicinity"? The second finding is that axial line distances to the nearest public green area correlated better than any metric measure with the questionnaire asking "How often do you visit your favourite park/nature area?" for ten city districts. The third finding is that the number of use values correlated with the number of staying visitors in five inner city parks, but not in six post-war parks of the same size. This confirms the theory of natural movement and the hypotheses that spatially integrated parks are probably more effectively used and have relatively more stakeholders.

There are two major conclusions to be made here. The first concerns the morphological design outcome and the second the planning process. Firstly, it seems that there are some urban designs that work better than others. The Swedish post-war modernist suburbs, as they have been fulfilled in Stockholm according to the General plan of 1952, have consequently got lower integration values, lower green space accessibility, and lower land use efficiency. In comparison, the Stockholm inner city grid, which has its park structure from 19th century regularism based on "the Lindhagen plan" from 1860, has more spatially integrated streets and green spaces. Consequently, the structural inefficiency of the post-war areas could open up for qualitative in-fill and restructuring, which can mean a denser city but higher green space accessibility. This has also been indicated by contemporary urban design theorists like Dolores Hayden, Peter Calthorpe and Xaveer De Geyter.

Secondly, concerning the planning process, there exists a locked situation where urbanists stand against environmentalists, 'dense' is against 'green'. The GIS-tools and the findings presented in this paper could, if they are considered as credible, help both parties see that urban design can be creatively used to understand land use efficiency and green space distribution equity. The tools and findings can in this way help overcome deadlocks and NIMBYISM in planning. In the end, much can be gained if the common opinion of open space and "green" changes from a static to a dynamic urban entity. 


\section{References}

Boverket (1999) Gröna områden i planeringen. Karlskrona: Boverket.

CNU (2000) Charter of the New Urbanism. New York: McGraw-Hill.

ECI (2003) European Common Indicators: Towards a Local Sustainability Profile. Milano: Ambiente Italia Research Institute.

De Clercq, EM., De Wulf, R. and Van Herzele, A. (2007) Relating spatial pattern of forest cover to accessibility. Landscape and Urban Planning 80:14-22.

Grahn, P. and Stigsdotter, U. (2003) Landscape planning and stress. Urban Forestry \& Urban Greening 2:1-18.

Harrison, C., Burgess, J, Millward, A. \& Dawe, G. (1995) Accessible natural green space in towns and cities: A review of appropriate size and distance criteria. Peterborough: English Nature. Research Report No.153.

Hayden, D. (2003) Building Suburbia: Green Fields and Urban Growth, 1820-2000. New York: Pantheon.

Hillier, B. \& Hanson, J. (1984) The social logic of space. Cambridge: Cambridge University Press.

Hillier, B., Penn, A., Hanson, J., Grajewski T. and Xu J. (1993) Natural movement: or, configuration and attraction in urban pedestrian movement. Environment and Planning $B$ 20:29-66.

Hillier, B. (2003) The Architectures of seeing and going: Or, are Cities Shaped by Bodies or Minds? And is there a Syntax of Spatial Cognition?. Proceedings of the 4th International Symposium in Space Syntax; London, pp.1-34.

Hörnsten, L. and Fredman, P. (2000) On the distance to recreational forests in Sweden. Landscape and Urban Planning 51:1-10.

Kaplan, R. and Kaplan, S. (1989) The experience of nature. Cambridge: Cambridge University Press.

Lancaster, R.A. (1987) Recreation, Parks, and Open Space Standards and Guidelines. New York: National Recreation and Park Association.

Lefebvre, H. (1995) Right to the city. Oxford: Blackwell.

MVRDV (1998) FARMAX: Excursions on density. Rotterdam: 010 Publishers.

Nozzi, D. (2003) Road to Ruin: An Introduction to Sprawl and How to Cure It. Westport: Praeger Publishers. 
Openshaw, S. (1984) The Modifiable Area Unit Problem: Concepts and Techniques in Modern Geography. Norwich: Geo Books.

Reneland, M. (1999) Samband mellan befolkningens avstånd till service och inslaget av grönytor i staden: Gis-projektet Tillgänglighet i svenska städer 1980 - 1995. Göteborg: Institutionen för stadsbyggnad, Chalmers Tekniska Högskola. Rapport 1999:3.

Sennet, R. (1992) The Conscience of the Eye: The Design and Social Life of Cities. New York: W.W. Norton \& Co.

Stockholms stad (1999) Stockholms översiktsplan -99. Stockholm: Kommunfullmäktige.

Stockholms stad (2005) Stockholms parkprogram Stockholm: Kommunfullmäktige.

Ståhle, A. (2005) Mer park i tätare stad: Teoretiska och empiriska undersökningar av. stadsplaneringens mått på friytetillgång. Licentiate thesis, Arkitekturskolan KTH, Stockholm.

Ståhle, A. (2006) Sociotope mapping: Exploring public open space and its’ multiple use values in urban and landscape planning practice. Nordic Journal of Architectural Research 4:2006.

Ståhle, A., Sandberg, A. and Nordström, M. (2003) Sociotophandboken: Planering av det offentliga uterummet med Stockholmarna och sociotopkartan. Stockholm: Rapport SBK 2003:2, Stadsbyggnadskontoret.

Ståhle, A., Marcus, L. and Karlström, A. (2005) Place Syntax - Geographic accessibility with axial lines in GIS. Proceedings of the 5th International Symposium in Space Syntax, Delft.

TEMO (2001) Så upplever stockholmarna sin stad: Med perspektiv på hållbar utveckling i stadsdelarna, Medborgarenkät 2001. Stockholm: Miljöförvaltningen.

Ulrich, R.S. (1984) View through a window may influence recovery from surgery. Science 224:420-421.

USK (2002) Situation och service i stadsdelen: Så tycker brukarna, jämförelser med 1996 och 1999. Stockholm: Utrednings- och statistikkontoret.

USK (2004) Stadsdelsinvånarna om miljö och miljövanor i Stockholm 2004: Medborgarenkät 2004, Stockholm: Miljöförvaltningen.

Van Herzele, A. \& Wiedemann, T. (2003) A monitoring tool for the provision of accessible and attractive urban green spaces. Landscape and Urban Planning 63:109-126.

World Commission on Environment and Development (1987) Our common future. Oxford: Oxford University Press.

Whyte, W. (1980) The social life of small urban places. New York: Project for Public Spaces. Xaveer De Geyter Architects (2002) After sprawl. Rotterdam: NAI Publishers. 